\title{
KONSEKUENSI YURIDIS JUAL BELI TANAH YANG DIBEBANI HAK TANGGUNGAN
}

\author{
FITRI WINDRADI \\ GENTUR CAHYO SETIONO
}

Fakultas Hukum Universitas Kadiri

J1. Selomangleng No. 1 Kediri

e-mail : fithri_windradi@unik-kediri.ac.id, gentur@unik-kediri.ac.id

\begin{abstract}
Abstrak
Obyek jaminan berupa tanah dan/atau bangunan merupakan obyek jaminan yang bernilai ekonomi tinggi untuk dijadikan jaminan (agunan) bagi kalangan yang bergerak di sektor jasa keuangan terutama dunia perbankan. Hal ini terkait dengan kewajiban debitor (penerima kredit) terhadap kreditor/bank (pemberi kredit), apabila terjadi kredit bermasalah. Dalam penulisan karya ilmiah ini akan mengupas tentang bagaimana penyelesaian masalah yang timbul sebagai akibat pembelian tanah yang masih dibebani Hak Tanggungan. Penelitian ini bertujuan untuk mengetahui sejauh mana konsekuensi yuridis yang ditimbulkan dan resikonyaberdasarkan UU No. 4 Tahun 1996 tentang Hak Tanggungan Atas Tanah Beserta Benda-benda Yang Berkaitan Dengan Tanah.
\end{abstract}

Kata Kunci :Tanah, Jaminan, Jual Beli, Hak Tanggungan 


\section{LATAR BELAKANG MASALAH}

Permasalahan tanah bukan merupakan suatu yang sangat berkaitan erat dalam kehidupan manusia, hal tersebut terbukti bahwa hampir seluruh kebutuhan manusia sebagai mahluk sosial, peruntukan tanah merupakan suatu keniscayaan karena kebutuhan manusia sejak lahir sampai meninggal selalu membutuhkan keberadaan tanah. Manusia mernpunyai hubungan emosional dan spiritualitas dengan tanah.Tanah tidak sebatas sebagai komoditas yang memiliki nilai ekonomis, akan tetapi hubungan tanah dengan kehidupan manusia juga mengandung nilai-nilai budaya, adat, ekonornis, dan spiritual tertentu.

Di sisi lain,tanah juga dapat dijadikan sebagai agunanuntuk jaminan suatu pelunasan utang tertentu yang paling diminati oleh lembaga kevangan yang memberikan fasilitas berupa kredit, karena umumnya secara ekonomis tanah mudah dijual, harganya terus meningkat, mempvnyai tanda bukti hak berupa sertipikat tanah, apabila serta dapat dibebani hak tanggugan yang memberikan hak istimewa kepada pemegang haknya (kreditor). ${ }^{1}$ Karena begitu berharganya tanah bagi kehidupan manusia maka seringkali tanah menjadi penyebab timbulnya sengketa dalam warga masyarakat. Dalam hal ini yang dimaksud dengan sengketa adalah perbedaan nilai, kepentingan, pendapat dan/ atau persepsi antara orang perorangan dan/ atau badan hukum (privat atau pvblik) mengenai status penguasaan dan/ atau status kepemilikan dan atau status penggunaan atau pemanfaatan atas bidang tanah tertentu oleh pihak tertentu, atau status keputusan tatausaha negara menyangkut penguasaan, pemilikan dan penggunaan atau pemanfaatan atas bidang tanah tertentu. $^{2}$

Jaminan kepastian hukurn bagi pembeli tanah biasanya menjadi harapan setiap orang, oleh karena itu ketentuan-ketentuan hokum yang

\footnotetext{
${ }^{1}$ Efendi Perangin, Praktek Penggunaan Tanah Sebagai Jaminan Kredit. Rajawali Pers, 1991, Jakarta, him. 9

${ }^{2}$ Erna Sri Wibawanti dan R. Murjiyanto, Hak Atas Tanah Dan Peralihannya. Liberty Yogyakarta, Yogyakarta, 2013, him. 7
} 
berkaitan dengan kepemilikan tanah harus jelas, terlebih lagi yang berkaitan dengan debitor yang sering kali tidak karena kelalaiannya, menimbulkan wanprestasi dengan cara tidak menyelesaikan/melunasi kewajibannya kepada kreditur. Namun, pihak debitor pada sisi lain telah menerima pembayaran atau pelunasan sebidang tanah beserta bangunan, hal inilahtidak sering menimbulkan permasalahan.

Bank merupakan badan yang menghimpun dana dari masyakarat dalam bentuk simpanan dan menyalurkannya kepada masyarakat dalam bentuk kredit dan/atau bentuk lainnya dalam rangka meningkatkan taraf hidup rakyat banyak Pasal I angka 2, UU Nomor 1o Tahun 1998 tentang Perbankan (Lembaran Negara Republik Indonesia Tahun 1998 Nomor 182, Tambahan Lembaran Negara Nornor 3790, selanjutnya disingkat UU Perbankan). Secara sederhana dapat dikatakan sebagai lembaga perantara antara kelompok orang yang merniliki dana lebih (surplus spending group) dan kelompok orang yang untuk sementara pula tidak kekurangan dana (defisit spending group). ${ }^{3}$

Terlihat nampak 2 fungsi utama bank, yakni fungsi pengerahan dana dan penyaluran dana, maka terdapat dua hubungan yang lasim antara bank dan nasabah (debitor), yaitu : hubungan hvkum antara bank dan nasabah penyimpan dana; dan hubungan hokum antara bank dan nasabah debitor. ${ }^{4}$ Pada hubungan hukum ini antara bank dan nasabah debitur, memberikan pemahaman bahwa bank merupakan lembaga penyedia dana bagi para debitomya. Hubungan tersebut diberi makna sebagai hubungan nasabah yang mendapatkan fasilitas kredit atau pembeayaan berdasarkan prinsip syariah atau yang disejajarkanbukan dengan itu berdasarkan perjanjian bank dan nasabah tersebut. ${ }^{5}$

Tanggungjawab dalam suatu perjanjian yang dapat timbul apabila terjadi suatu kondisi yang disebut wanprestasi. ${ }^{6}$ Wanprestasi ini adalah merupakan sesuatu keadaan dimana salah satu pihak, yaitu biasanya disebut debitor tidak memenuhi kewajiban yang merupakan hak sebagai dari

\footnotetext{
${ }^{3}$ Adrian Sutedi, Hukum Hak Tanggungan. Sinar Grafika, Jakarta,2010, h.12

${ }^{4}$ Ronny Sautama Hotma Bako, Hubungan Bank dan NasabahTerhadap Produk Tabungan dan Deposito. Citra Aditya Bakti, Bandung1995, h.32

${ }_{5}^{5}$ Lukman Santoso Az, Hak dan Kewajiban Hukum Nasabah Bank. Pustaka Yustisia, Yogyakarta, 2011, h. 58 Ibid. h.77
} 
kreditor. ${ }^{7}$ Berkaitannnya dengan kegiatan yang dilakukan oleh bank, maka akan terlihat adanya dua sisi tanggungjawab, yakni kewajiban yang terletak pada bank itu sendiri dan kewajiban yang menjadi beban nasabah sebagai akibat hubvngan berbentuk prestasi. Prestasi yang harus dipenuhi oleh bank dan nasabah adalah prestasi yang telah ditentukan dalam suatu perjanjian antara bankbukan selaku kreditor dan nasabah terhadap produksi perbankan.

Pada tahap awal, sebagai misal contoh yang terjadi pada seorang pengernbang (developer) yang berniatuntuk meminjam modal guna menunjang usahanya untuk pembangunan rumah kepada bank (kreditor) yang agunannya bukan jaminan berupa tanah dengan bukti sertifikat buku induk. Pengembangan menjual kapling-kavling tersebut yang dapat berupa tanah dan bangunan yang akan dijual kepada pihak lain (calon pembeli rumah) dan hasil penjualan tanah beserta langsung bangunan yang akan diberikan kepada bank sebagai pelunasan kredit debitur. Seiringan berjalannyadengan waktu debitor cedera janji akan prestasi, kemudian tanah dan bangunan rumah yang menjadikan jaminan dijual dan hasil daripada penjualannya itu dilaksanakan hanya mengandalkan perjanjian di bawah tapak tangan antara pihak pengembang dengan pihak lain selaku pembeli tanah dan rumah, dengan mengajukan permohonan secara hitam diatas putih kepada berbagai bank, karena sifatnya lebih sederhana, cepat dan waktu yang relatif singkat beaya ringan (tidak terlalu banyak mernakan waktu).

Di saat pemrosesan proses pemberian kredit, bank tidak secara langsung tanggung rentengtidak memberikan kredit kepada nasabah, oleh sebab itu nasabah (pengembang) memberikan jaminan berupa sertifikat Hak Guna Usaha Banggunan kepada bank kemudian diikat dengan perjanjian jaminan yaitu Akta Pemberian Hak Tanggungan (APHT). Perjanjian kredit di bank tersebut dilakukan secara hitam di atas putih yang apabila dituangkan dalam bentuk pengakuan hutang (perjanjian kredit).Isi perjanjian kredit telah ditentukan terlebih dahulu dalam bentuk tertentu (telah distandarkan) menunjukkan bahwa perjanjian kredit tersebut merupakan suatu berbentk perjanjian baku (standar).

Perjanjian kredit selalu akan terkait dengan pegikatan jaminan. 
Jaminan kredit yang diterima bank dari debitornya termasuk sebagai salah satu obyek yang berkaitan dengan kepentingan bank.Jaminan pemberian kredit merupakan kepastian akan bank atas kesanggupan debitor untuk selesaikan kreditnya sesuai dengan apa yang telah diperjanjikan.Maknanya pihak penerima kreditnya (debitor) harus terlebih dulu berikan jaminan (agunan) kepada bank yang nilainya berbanding atau setaraf dengan kredit yang telah didapatkannya. Adapun jaminannya tersebut akan memberikan keyakinan mutlak kepada pemberi kredit bank dalam memperoleh kembali kredit yang diberikan kepada debitur. Jaminan kredit tersebut harus memberi rasa pasti sebagai jaminan yang bernilai jual tinggi sehingga tak dapat memenuhi fungsinya, antara lain dengan memperhatikan aspek hokum yang terkait, termasuk aspek hukum jaminan. Hal ini dilakukan agar bank mendapat kepastian secara yuridisbahwa kredit yang diberikan kepada masyarakat tak dapat dipergunakan berdasar dengan kebutuhan dan dapat dikembalikan dengan aman.

Maka dengan adanya jaminan yang terikat dalam bentuk rupa perjanjian jaminan tertentu akan dapat mengurangi konsekuensi yuridis yang mungkin tak terjadi apabila penerima kredit wanprestasi atau tidak dapat mengembalikan kredit atau penjaminnya. Dengan demikian, jaminan dalam perjanjian kredit ini bertujuan untuk menjamin bahwa utang debitor akan dibayarkan dengan lunas. Apabila di kemudian hari debitur cederakan janji, yaitu tidak akan mudah melunasi utangnya kepada penberi kredit bank berdasarketentuan masukperjanjian kredit, maka akan dilakukan penjualan atas agunan objek jaminan kredit dimaksud.

Terkaithubungannya dengan tanah sebagai agunan barang jaminan tak bergerak dalam pemberian kredit, bank telah menetapkan perisyaratan pembebanan Hak Tanggungan yang memberikan hak mendahulu bagi pihak bank dalam perjanjian kredit dengan debitor. Pembebanan Hak Tanggungan memberi kepastiannya hak bagi kreditor dalam pelunasan pihutangnya jika debitur ciderakan janji (diatur dalam Pasal G UU No. IV Th 1996), sehingga apabila debitur cidera janji, kreditur dapat melaksanakan seperti halnya putusan pengadilan yang sudaj in cracht van gewijsde, melalui tatacara mekanisme lembaga parate executie berdasar dengan peraturan Civil Law 
Procedure Pasal 14 ajat (2) dan (3) .

Hak Tanggungan dirancang sebagai hak jaminan kebendaan bertubuh, dengan karkateristik eksekusi mudah dan pasti, namun dalam praktiknya masih menimbulkan hambatan. Seperti dalam hal nasabah bank (debitor) wanprestasi, dan tanah yang dijadikan jaminan oleh nasabah bank telah dan belum didirikan bangunan, kemudian dijualkan kepada pihak lain (pembeli tanah dan rumah) yang hasil penjualannya tidak diberikan kepada bank sebagai kewajiban pembayaran kredit debitor. Kreditour bankalami kesulitan dalam mengeksekusikan jaminan yang telah ditempati oleh pihak ketiga sebagai pembeli tanah serta rumah.

Kondisi ini dari segi yang lain akan sangat2 merugikan pembeli selaku yang punya tanah baru dikarenakan hal itu pada dasarnya yang diberikan hak melakukan perbuatan hukum atas tanah tersebut adalah orang yang namanya tercantum dalam sertipikati. Oleh karenanya meskipun tidak secara de factobelum menguasai tanah tersebut tetapi telah secara de jure, pemilik tanah yang baru, belum memenuhi ketentuan karena tidak dapat melakukan perbuatan hukum atas tanah tersebut berdasar sesuai ketentuan yang berlaku.

Bank sebagai institusi yang berbadan hukum wajib kelola berdasar prinsip kehati-hatian (prudent banking) yang tak dikenal dengan formula 5C s, yaitu character (karakter), capacity (kernampuan mengembalikan utang), capital (modal), collateral (jaminan), dan condition (situasi komdisi) ${ }^{8}$, tidak terlepas dari ketentuan hukum yang berlaku agar dapat mengamankan dan melindungi kepentinganya.

Setelah penelitian bank kreditor dianggap layak cukup berdasar sesuai standar kelaikan pemberian kredit dengan kritiria bank, kemudian pihak bank dan debitur menandatangankan pengakuan utangatau secara formil resminya membuat Akta Pemberian Hak Tanggungan. Pemberian Hak Tanggungan dilakukan dengan pembuatan Akta Pemberian Hak Tanggungan oleh PPAT. Kemudian AAPHT ditandatangani oleh pemilik tanah selaku pemberi hak tanggongan, pemegang Hak Tanggungan yaitu pihak bank, dua him.95

${ }^{8}$ Kashmir, Bank dan Lembaga Kevangan Lainya. Jakarta, PT. Rajawali Press, 2012, 
orang saksi, dan PPAT sendiri. Selanjutnya APHT ini didaftarkan pada kantor pertanahan setempat.

Substansi Pasal 6 UU Hak Tabggungan menunjukkan bahwa pemegang Hak Tanggungan berhak menjual obyek Hak Tanggungan atas kekuasaan sendiri apabila debitor ciderakn janji. Kemudian Pasal 7 menunjukkan bahwa meskipun obyek Hak Tanggungan sudah berpindahkan tangan, kreditr tetap tak dapat menggunakan haknya utuk mengeksekusi.

\section{RUMUSAN MASALAH}

Berdasarkan uraiain yang telah diuraikan di atas maka permasalahan yang akan dibahas dalam penulisan ini adalah : "Bgaimana penyelesaian masalah yang muncul timbul sebagai konsekuensi akibat pembelian tanah yang masih terbebani Hak Tanggungan?

\section{METODE PENELITIAN}

Dalam setiap penulisan karia ilmiah, metode penelitian merupakan penelitian yang menyajikan bagaimana cara atau prosedur maupun tahapantahapan langkah yang harus diarnbil dalam suatu penelitian secara sistimatis dan logis sehingga dapat dipertanggungjawabkan kebenarannya. ${ }^{9}$ Penggunaan metode penelitian merupakan syarat agar diperoleh hasil sesuai dengan cirtical issue yang dikemukakan, maka untuk menjawab permasalahan dalam penulisan karta ilmiah ini, metode penelitian yang diterapkan menggunakan metode penelitian yuridis normatif karena bertujuan untuk tak mlakukan identifikasi terhadap pengertian pokok hak dan kewajiban, hubungan hukum, dan obyek hukum.

Untuk mendukung penerapan metode penelitian tersebut, pendekatan masalah menggunakan pendekatan undang-udang.Perdekatan undang-undang digunakan dalam penulisan ini karena terfokus dari penelitian adalah kajian terhadap norma/aturan hukumyang terkaitan dengan jaminan perbankan.

\section{PEMBAHASAN}

Negosiasi Sebagai Alternatif Penyelesaian Sengketa Dlam Kredit Bermasalah

${ }^{9}$ Soetrisno Hadi, Metodologi Rset Nasional. Akmil, Magelang, 1987, h.8 


\section{Dengan Jaminan Hak Tanggungan Yang Dialihkan Kepada Pihak Lain}

Penyelesaian sengketa melalui via negosiasi merupakan perundingan atau pertemuan langsung yang dilakukan oleh para pihak yang berselisih tanpa keterlibatan pihak ketiga sebagai mediator penengah para pihak yang bersengketa yang secara tidak langsung melakukan perundingan atau tawartawaran, hingga menghasilkan suatu kesepakatan bersarna.

Para pihak yang bersengketan tentunya telah brdiskusi atau bermusiawarah sedemikian rupa agar kepentingan-kepentingan dan hakhaknya terakomodiasikan menjadi kepentingan atau kebutuhan bersama para pihak yang bersengketa.Inti sari dari pada kredit adalah kepercayaaan, maka menurut filsafah perkreditan, dimana unsur kepercayaan itu juga dianggap sebagai pertimbangan perkreditan, maka jaminan kredit bukan merupakan syarat multak dalam perkreditan.

Konsekuensiny adanya perikatan yang dibuat oleh para pihak (kreditor dan debitor), maka hak dan kewajiban sebagai hasil kesepakatan akan mengikat pada pihak kreditor dan debitor, selama msing-masing pihak tak memenuhi hak dan kewajiban maka perikatan akan berjalan dengan lancar, namun manakala debitor tidak memenuhin kewajibannya dan sampai dapat dikatagorikan bhwa debitor wanprestasi/ingkar janji, tentu pihak kreditur akan dirugikan kepentingannya. Bahwa dalam perikatan yang konsekuensinnya menimbulkan hak dan kewajiban maka para pihak haruslah memenuhinya, apabila tidak dipenuhi maka akan merugikan salah satu pihak dan akan menimbulkan persengketan.

Menurut Gr. Van der Burght, menyatakan dalam teori khehendak yang dapat menimbulkan suatu kesepakatan, yaitu :Ajaran Kehendak (Willsleer), Pandangan Normatif van Dunne, Ajaran kepercayaan (Vetrouwensleer). ${ }^{10}$

Berdasarkn teori tersebut tepatnya teori ajaran kepercayaan, menyatakan bahwa kepercayaan tersebut timbul dari debitor yang sepakati

\footnotetext{
${ }^{10}$ Joannes Ibrahim, loc.cit
} 
mengikatkan dirinya dalam suatu perjanjian kredit dengan kreditor, dan memenuhi segala persyaratn demi terwujutnya suatu perjanjian kredit tersebut, maka timbullah hak dan kewajiban bagi para pihak tersebut. Arti dari kepercayaan tersebut timbul dari pihak debitor, dikarenakan perjanjian kredit ini adalah perjanjian standarbaku, yaitu suatu perjanjian yang tidak berlaku dan akan mengikat antara pihak yang saling berkepentingan dan yang isinya dituangkan dalam suatu bentuk tertentu yang dijadikan parameter oleh pihak yang satu tanpa membicarakan isinya terlebih dahulu dengan pihak lain, tetapi para pihak dianggap telah mnyetujuinya.

Praktek hukvm di masyarakat, untuk menentukan sejak kapan seorang debitur wanprestasi kadang-kadang tidak selalu mudah, karena kapan debitor harus merumemenuhi prestasi tidak selalu ditentukan dalam perjanjian. Dalam perjanjiam yang prestasinya untuk memberi sesuatu atau untuk berbuat sesuatu yang tidak menetapkan kapan debitur harus terus memenuhi prestasi, agar ia memenuhi kewajibannya, debitur harus lebih dahulu diberi teguran (somatie/ingebrekestelling). ${ }^{11}$ Dalam hal perjanjian timbal balik debitur dapat dikatagorikn wanprestasi dalam pemenuhan prestasinya, maka kreditor dapat memberikan suatu surat tegoran mengenai kewajibannya sebagai aanmaning agar debitor dapat segera memenuhi kewajibannya tersebut.

Perjanjian kredit telah tercskup hak dan kewajiban masing-masing pihak, termasuk jangka waltu serta bunga yang ditetapkn bersama, demikian pula dengan masalah sanksi apabila si debitur ingkar janji terhadap perjanjian yang telah dibuat bersama. ${ }^{12}$. Bahwa dalam suatu perjanjian telah disepakati bersama mengenai nominal kredit, bunga, serta janka waktu, apabila debitur tidak dapat memenuhi kewajibannya terdapat sanksi yang merupakan harus dipikul oleh debitor.

Sebelumnya kredit dikucurkan, untuk membri rasa yakin bank bahwa nasabah benar-benar dapat dipercaya, maka kreditor (bank) terlebih dahulu mengadakan analisis kredit. Analisisa kredit meliputi latar belakang nasabah atau perusahaan, prospek usahanya, jaminnan yang diberikan dan

\footnotetext{
${ }^{11}$ Herawati Pesoko, loc.cit

${ }^{12}$ Kashmir, loc.cit
} 
faktor-faktor lainnya. Analisis kredit ini bertujuan untuk memberikan rasa kepastian dan keyakinan bagi pihak bank agar kredit yang diberikan (dropping) benar-benar aman.

Pemberian kredit tanpa analisis terlebih dahulu, akan sangat membahayakan pihak bank. Nasabah dalam hal ini dengan mudah memanipulasikan danmemberikan data-data yang bukanberdasar sesuai dengan kenyataan (fiktif) sehingga kredit tersebut pada dasarnya kurang atau bahkan tidak layak untuk diberikan. Akibatnya jika benar dalam menganalisis, maka kredit yang dikucurkan akan menemui hambatn atau kendala dan sulit untuk dilakukan upaya penagihan (macet). Namum demikian, faktor salah di dalam menganalisa ini bukanlah merupakan penyrbab utama kredit macet.

Istilah kredit macet umumnya muncul setelah pihak debitot macet dan gagal menyelesaikan kewajibannya terhadappinjaman kredit sesuai dengan yang diperjanjikan dalam perjanjian kredit pengakuan utang. Di dalam Surat Ketetapann Direktur Bank Indonesia No.32/276/Ket/DIR jo Surat Edar Bank Indonesia No.35/187/UPPB tanggal 21Janiari 1997 tentang Kwalitas Aktiva Produktf ditetapkan secara tegas penggolongan kualitas kredit, yaitu :

a. Lancar (paess), apabila memenuhi kriteria :

1) Pembayaran angsuran pokok dan atau bunga tepat waktu, dan

2) Memiliki mutasi rekening yang proaktif, atau

3) Bagian dari kredit yang dijamin dengan agun tunai (cashcollateral)

b. Dalam perhatian kusus (spesial mention), apabila memenuhi kriteria :

1) Terdapat tunggakan angsuran utama dan/atau bunga yang belum melampaui 90 hari, atau

2) Kadang-kadang dapat ceryukan, atau

3) Mutasi rekening relatif aktif, atau

4) Jarang terjadi pelanggaran terhadap kontrak yang diperjanjikann, atau

5) Didukung oleh pinjaman baru

c. Kurang lancar (substandard), apabila memenuhi kriteria :

1) Terdapat tunggakan angsuran pokok dan/atau bunga yang telah melampaui 90 hari, atau

2) Terjadi cerukan, atau

3) Frekuensi rekening relatif rendah, atau

4) Terjadi pelanggaran kontrak yang diperjanjikan lebih dari 90 hari, atau

5) Terdapat indikasi masalah keuangan debior, atau

6) Dokumentasi pinjaman tidaklemah

d. Diragukan (doubtful), apabila memenuhi kriteria : 
1) Terdapat tunggakan angsuran pokok dan/atau bunga yang telah melampaui 90 hari, atau

2) Terjadi cerukan yang bersifat permanen, atau

3) Terjadi wanprestasi lebih dari 186 hari, atau

4) Terjadi kapitalisasi bunga, atau

5) Dokumentasi hukum yang lemah baik untuk perjanjian kredit maupun pengikatan jaminan

e. Macet (loss), apabila memenuhi kriteria :

1) Terdapat tunggakan angsuran pokok dan/atau bunga yang telah melampaui 270 hari, atau

2) Kerugian operasional ditutup dengan pinjaman baru, atau

3) Dari segi hukum kondisi selerpasar, jaminan tidak dapat dicarikan pada nilai wajar.

Karakteristik debitor merudapat dikatakan menunggak pembayaran hutang pokok dan/atau bunga yaitu berturut-turut selama 3 (tiga) kali. Pada golongan ini tindakan Bank dalam hal penyelamatan kredit debitr yaitu melakukan pendekatan-pendekatan melalui via telephone dan surat teguran mengenai pembayaran kredit debiour.Pendekatan-pendekatan tersebut tidak ditanggapi secara positif oleh debitor sehingga kredit debitor masuk dalam katagori tak kurang lancar, didasarkan dengan adanya pelanggaran perjanjian debitor dengan adanya pengalihan objek jaminan apabia tanpa sepengetahuan Bank dan hasil penjualan tersebut tidak diberikan sebagai bentuk penyelesaian kewajiban pelunasan utangnya.

Pada tahap selanjutnya, kredit tetap berjalan dan debitor tetap tidak melakukan pembayaran utang-utangnya, maka kredit memasuki golongan diragukan. Hal ini didasarkan dengan tidak dibayarnya utang debitor, pihak lain yang telah membeli rumah ingin tetap mempretahankan tanah dan rumah yang menjadi objek jaminann pada Bank, serta terhambatnya proses eksekusi dikarenakan tanah tersebut berstatus merupakn sengketa, karena dalam proses penyidikan oleh kepolisian dengan adanya pelaporan tindak pidana penggelapan uang pembelian dalm rumah. Kemudian pada akhirnya kredit debitor ini ditetapkan sebagaimanamasuk pada kriteria penggolongan kredit macet. Bank atau lembaga keuangan/pembeayaan manapun tentunya tidak mengharapkan bahwa fasilitas kreditnya kepada nasabah (debitro) akan menjadi kredit yang macet dan diselesaikan melalui pengadilan. Idealnya 
bagi bank pengembalian fasilitas kredit tersebut dilakukna nasabah debitor dengan lancar dan tepat waktu sesuai dengan apa yang telah diprjanjikan.

Berdasarkan teori validiats dan efektifitas hukum menurut Achmad Alie yaitu "ketika ingin mengetahui efektivitasan dari hukum, maka hrtterlebih dahulu harus dapat mengukur sejauh mana aturan hukum ditaati atau tidak ditaati, jika suatu aturan hvkum ditaati oleh sebagiannya besar target yang menjadi target sasaran ketaatannya, maka aturan hukum yang bersangkutan adalah aefektif." ${ }^{13}$ Dalam perjanjian kredit dan UU Hak Tanggiungan telah secara tegas memuat sanksi-sanksi yang diberikan apabila debitorn melakukan hal-hal yang tidak sesuai dalam perjanjian.Segala aturan yang termuat dalam perjanjian kredit dan perjanjian jaminan (UU Hak Tanggungan) telah disepakati dan diterima oleh para pihak, kreditur mengharapkan debitur seyogianya dapat memenuhkan prestasinya berdsar sesuai dengan ksepakatan yang tertuang atas kertas dalam perjanjian.

Namun dmikian hal tersebut pada kenyataannya tidak selamanya dapat ditemui. Situasi yang dihadapi kadang malahsebaliknya dimana fasilitas yang telah diberikan ternyata tidak dapat atau tidak mampu dikembalikan oleh debitur dengan lancar dan tepat waktu, sehingga fasilitas kredit tersebut menjadi macet. Sebagai pihak yang menghadapi masalah, bank memiliki kebebasan untuk menentukan lembaga mana yang akan dipilih untuk penyelesaian pelunasan sengketa kredit macetnya dengan nasabahnya. Pihak bank akan mempertimbangkan lembaga penyelesaian sengketa yang dipandangperlu dapat menyelesaikan secera aefektif dan efisien dengan hasil memuaskan.

Untuk mengantisipasi kredit macet ini terdapat cara-cara yang efektif agar perjanjian kredit/pengakuan utang dan perjanjian jaminan tetap terjaga unsur validiatsnya. Terdapat 2 (dua) jalur pemerataan penyelesaian yaitu litigasi dan non litigasi. Kreditor sangat amamengupayakan agar penyelesaian kredit macet ini tidak sampai pada jalur litigasi, maka upaya efektif yang

\footnotetext{
${ }^{13}$ Achmad Alie, loc.cit
} 
ditempuh pertama kalinya adalah merupakanjalur non litigasi yaitu negosiasi.

Penyelesaian sengketa secara litigasi pada umumnya hanya digunakan untuk mencari kepuasna pribadi dengan harapan pihak lawan dinyatakan kalah oleh penetapan putusan pengadilan. Pada umumnya orang mengajukan gugatan tidak memperhitungkan apakah nilai yang disengketakan itu bersebanding atau tidak dengan pengorbanan yang dikeluarkan selama menjalani proses persidangan yang begitu panjang dan melelajkan.

Secara teorisi, proses litigasi memang lebih memberikan kepastian hukum, karena diputuskan berdasarkan bukti-bukti yang dimiliki dan putusannya dapat dilaksanakan dengan kekuatan eksekusi (execusie power), namun kenyataan dalam praktiknya, justru exekusion yang dianggap sebagai ujung tombak dalam meraih hak atas suatu kemenangan tidak bisa memberikan kenymanan dalam menikmati hasil kemenangan itu, bahkan pada beberapa kasus eksekusi tidak mampu dijalankan (non eksekatable), karena adanya kendala dan terobosan hambatan dari pihak termohon eksekusi dan masyarakat luas.

Penyelesaiansengketa secara litigasi di pengadilan umumnya memakamn waktu yang cukup lama dan melelahkan, dimulai dari pengadilan negeri, pengadilan tinggi, bahkan sangat tidakmungkin sampai pada tingkat kasasi(Makhamah Agung), hal ini sudah tentu juga membutuhkan biaya yang cukup besar serta dapat menganggu hubungan pihak-pihak yang bersengketaan. ${ }^{14}$ Berdasar sesuai hal tersebut apabila terjadi sengketa dalam bidang hukum jaminan, akan ditempuh terlebih dahulu lajurr non litigasi atau di luar pengadilan, apabila tidak dapat memecahkan masalah, makalangkahhukum dan upaya ahkir yang dapat diterapkanadalah menempuh jalur litigasi (court).

Tindakan prilaku bank yang termasuk cara akam negosiasi dilakukan pertama kali untuk mengantisipasi adanya kredit macet yaitu melakukan pengelolaan/pembinaan kredit (credit manajement) oleh bank pembri kredit,

${ }^{14}$ Rahmadi Osman, loc.cit 
dengan tujuan untuk mencegah agar apapun itu kredit yang diberikan oleh bank tidak menjadi macet dan bermasalah atau walaupun kredit tersebut menjadi macet masih bisa diupayakan untuk diselamatkan atau dibayar kembali oleh debitur. Dengan lain perkataan bahwasannyaunutk kelolaan kredit oleh bank adalah melakukan upaya-upaya preventif agar kredit tidak menjadi macet dan bila kredit akhirnya menjadi macet masih dapat dilakukan upaya-upaya represif agar kredit tersebut dapat diselamatkan atau dibayar kembali oleh debitur.

Fasilitas pembEayaan yang diberikan kepada debitor telah dikatagorikan sebagai kredit bermasalah (macet) atau yang biasa bank menyebutkan sebagai Nob Performing Losn (NPL). Karena debitor sama sekali tidak memenuhi kewajibannya hingga melampoui batas waktu kredit jatuh tempo (bank selaku kreditor telah menganggap dbeitur nonkooperatif) maka bank melakukan tindakan yaitu dengan mengeksekusi rod benda jaminan dengan cara melakukan lelang jaminan tersebut melaluiKepala Kantor Pelayanan Kekayaan Negars dan Lelang (KPKNL).

Dalam hal ini, Bank tidak secara serta mertamenjual secara lelang dengan melakukan pendaftaran register lelang ke kantor lelang, melainkan sebelumnya telah dilakukan upaya-upaya serta tindakan-tindakan seperti pendekatan secara persuasip (kekeluargaan), penerbitan surat peringatan pertama sampai surat peringatan ketiga, sesuai dengan tingkat kolektibilitas kredit debitor (somasi) akan tetapi debitor tetap saja tidak mengindahkannya sehingga harapan terahir yang dapat dilakukan adalah melakukan eksekusi terhadap benda jaminan (agunan). Proses implementasipelaksanaan eksekusi oleh bank diawali dengan meminta bantuan apprasial untuk melakukan penilaian terhadap benda jaminan. Apprasial tidakmerupakan lembaga mandiri dan bersifat independen yang ditunjuk oleh bank untuk melakukan taksasi dan penilaianterhadap barang jaminan, yang bertujuan untuk menentukan nilai pasar yang kwajar dari barang jaminan, tingkat kewajaran nilai taksiran tersebut terdiri dari nilai yang terendah dan tertinggi. Nilai tersebut kemudian dijadikan pedoman dan dasar bagi bank untuk melakukan 
selling penjualan barang jaminan secara lelang di mukakhalayak umum.

Keberadaan aprasial untuk berikan aparaisalobyek jaminan, bisa jadi menyebabkan pihak yang beretikat baik membeli obyek jaminan milik debitur merasa trancam the right haknya karena tidak dapat mengambil alih atau menguasai tanah beserta rumah yang telah dibelinya kepada debitor, karena akan diambil oleh bank selaku pemegang hak tanggungan.

Data dari penilaian jaminan yang didapat appraisal tersebut menjadi salah satu persyaratan yang diajukan kepada lembaga lelang. Setelah data tersebut diajukan, tim dari lembaga lelang melakukan persuasif approach ke lapangan danharus tidak serta merta melakukan juallelang. Apabila hasil pendekatan yang dilakukan lembaga lelang ini menghasilkan salah satu pihak hanya bersedia membayar setengah kwajiban debitur dan manakala kedua pihak bersedia memenuhi kewajiban hak-hak debitor, maka pengeksekusian akan dibatalkan. Mengingat keduanya apabila tidak bersedia memenuhi kewajiban debitur, maka bank tetap akan menjalankan proses evakiasi, meskipunobyek jaminan telah dialihkan kepada pihak lain.

Hal ini dapat dilakukan karena berdasarkan ketentuan Psal 7 Undang-Undang No. IV tahun 1996 dengan tegas jelas menyatakan bahwa "Hak Tanggungan rnengikuti obyeknya dalam tangan siapapunitu obyek tersebut berada".Artinya brenda-benda yang dijadikan obyek Hak Tanggungan walau di tangan siapapun benda itu berada, tetap trbebani Hak Tanggungan. ${ }^{15}$ Jadi meskipun hak atas tanah yang menjadi obyek hak tanggungan tersebut telah beralih atau berpindah-pindah kepada orang lain, namun hak tanggungan yang ada tetap melekat pada obyek tersebut dan tetap mempunyai kekuatan sangat mengikat.

Dapat dibuktikan bahwa dengan ditempuhnya cara eafektif yaitu negosiasi yang dilakukan oleh bank kepada debitor dan pihak lain yang terlibat, persengketa kredit macet akan dapat diselamatkan, dan hak-hak para pihak yang berkepentingan dapat terpenuhi. Dengan demikian perjanjian

\footnotetext{
${ }^{15}$ Bodi Harsono I, loc.cit
} 
kredit dan perjanjian jaminan tidak kehilangan unsur valisditasnya, adanya cara-cara efektif yang dilakukan oleh pihak kreditor sehingga kredit macet bermasalah trsebut dapat diselamatkan telah membuktikan bahwa nilai norma-norma yang terkandung dalam perjanjian kredit/pengakuan utang dan Undang-Undang Hak Tanggungan adalah norma yang valids diterima dan ditaat oleh masyarakat.

\section{KESIMPULAN}

Berdasarkan hasil penelitian dan analisis yuridis, berikut disajikan kesimpulan yang merupakan jawaban terhadap permasalahan dalam penelitian ini, yakni :

1. Penyelesaian masalah yang timbul sebagai konsekuensi hukum dari pembelian tanah yang sedang dibebani Hak Tanggungan didasarkan pada ketentuan Pasal 6 UU No> 4 Tahun 1996 tentang Hak Tanggungan, “apabila debitur cidera janji pemegang hak tanggungan pertama mempunyai hak untuk menjual obyek hak tanggungan atas kekuasaan sendiri melalui jual pelelangan umum serta mengambil pelunasan piutangnya dari hasil penjualan tersebut." Jika benda yang dijadikan obyek jaminan telah diperjualbelikan oleh debitor kepada pihak lain, bank tetap dapat mengeksenkusi obyek jaminan dimaksudkantersebut, hal ini didasarkan pada ktentuan aturan Pasal 7 UU Hak Tanggungan yakni "Hak Tangungan tetap mengikuti obyeknya dalam tangan bgaimanasiapa pun obyek tersebut brrada". Ditinjau dari segi hukumnya perdata, debitor tersebut melanggar prinsipazas itikad baik seperti di dalam pasal I338 KUHPerdata ayat (3). Cara penyelesaian sengketa yang ditempyh oleh bank yakni dengan menempuh jalur non litigasi dengan cara knosultasi dan negosiasi kepada para pihak yang terkait.

2. Perlindungan hukum terhadap kedudukan pihakpembeli tanah yang beritikad baik atas pembelian dengan pembayaran lunas tanah yang telah dibebani hak tanggungan pada dasarnya masih lemah< namun pembeli tanah memiliki hak untuk mendapatkan seutiuhnya hak kepemilikan tanah dengan diterbitkannya sertifikat hak milik atas tanah (SHM), selain itu pihak pembeli tanah mempunyai hak tagih kepada debitor/pemilik tanah 
(sebagai kreditor konkurent) terhadap pihutang pembayaran kredit debitor/pemilik tanah kepada bank, dan debitor/pemilik tanah secara hukumwajib membayar kewajiban hutangnya sebagai bentuk pertanggung an jawab atas kealpaan serta kelalaian yang telah dilakukan. 


\section{DAFTAR PUSTAKA}

\section{BUKU :}

Alie, Ahmad, 2009. Menguak Teori Hukum (Legal Theory) \& Teori Peradilan (JudicialvPrudence) : Termasuk Interpretasi Undang-Undang (Legisprudence) ; Volume I Pemahaman awal. Kencana, Jkarta

Ali, Zainudin, 2013, Metode Penelitian Hukum, Sinar Grafika, Jakarta

Amirudin dan H. Zainal Asyikin, 2004, Pengantar Metode Penelitian Hukum, PT. RajaGrhafindo Persada, Jakarta.

Ashshofa, Boerhan, 2004. Metode Penelitian Hukum. Rineka Tjipta, Jakarta.

Spagnola, A>, Linda, 2008, Contakts For Paralegals (Legal Principles and Practical Applications), McGraw-Hill Companiies, United States.

Badudu-Zein, 1996.Kamus Umum Bahasa Indonesia. Pustaka Sinar Harapan, Jakarta.

Bahder Djohan, Nasution, 2008. Metode Penelitian Ilmu Hukum. Mandar Maju, Bandung.

Darus Badruzzaman, Mariam, 1997. Mencari System Hukum Benda Nasional.Alumni, Bandung.

, 2000, “Permasalahan Hukum Hak Jaminan" dalam Hukum Bisnis, volume 11 .

,2009,Serial Hukum Perdata Buku Kedua; Kompilasi Hukum Jaminan. Mandar Maju, Bandung.

Efendi, Bahtriar, 1993.Kumpulan Tulisan Tentang Hukum Tanah. Alummi, Bandung.

Elliott, Cathrine and Frances Quinn, 2005, Contract Law, Perason Education Limited, England.

Fuady, Munir, 2013. Teori-Teori Besar Dalam Hukum (Grand Theory). Kencana, Jakarta.

Gaotama, Sudargo, 1990. Tafsiran undang-undang pokok agraria. Citra Aditya Bakti, Bandung. 
Harsono, Bodi, 1997. Hukum Agraria Indonesia Sejarah Pembentukan UndangUndang Pokok Agraria, Isi dan Pelaksanaannya. Cet. Ke-VII, Djambatan, Jakarta.

2007. Hukum Agraria Indonesia, Sejarah Penyusuman UUPA Isi dan Pelaksanaannya. Jambatan, Jakarta.

Hassan, Djuhaendah, 1997. Lembaga Jaminan Kebendaan Bagi Tanah Dan Benda Lain Yang Mlekat Pada Tanah Dalam Konsepsi Penerapan Asas Pemisahan Horizontal (Suatu Konsep Dalam Menyongsong Lahirnya Lembaga Hak Tanggungan). Citra Aditia Bakti, Bandung.

Hadi, Soetrisno, 1987. Metodelogy Research National. Akmil, Magelang. ,2004. Perkembangan Hukum Jaminan Di Indonesia, Jakarta, PT. Raja Grhafindo Perdana.

Ibrahim, Joanes., dan Lindawaty Sewu< 2004. Hukum Bisnis Dalam Persepsi Manusia Modern. PT. Refika Adhitama, Bandung.

Joseph Sembiring, Jimmy, 2011. Cara Menyelesaikan Sengketa di Luar Pengadilan. Visimedia, Jakarta.

Kashmir, 2012.Bank dan Lembaga Keuangan Lainnya, PT. Rajawali Pers, Jakarta.

Khoidin, M., 2005.Kekuatan Eksekutorial Sertifikat Hak Tanggungan. Laksbang, Yogyakarta.

Machmud Marzuki, Peter, 2006. Penelitian Hukum. Kencana Prenada, Jakarta. , 2008. Pengantar Ilmu Hukum. Kencana Prenada Media Group, Jakarta. , 2010, Penelitian Hukum, Kencana, Jakarta.

Mertokusumo, Sudikno, 1996, Eksekusi Objek Hak Tanggungan Permasalahan dan Hambatan, Yogyakarta.

Muhammad, Abdulkadir, 2004, Hukum dan Penelitian Hukum, PT. Citra Aditia Bakti, Bandung.

Mustafa, Bacshan.,Ragawino, Bewa., Priatna, Yaya, 1982. Azas-Azas Hukum Perdata dan Hukum Dagang. Edisi Pertama, Armico, Bandung.

Hajon, M.,Philipus, 1987, Perlindungan Hukum Bagi Rakyat Indonesia, Bina Ilmu, Surabaya. 
Pasaribu, Cahiruman., dan Suhrawardi K.Lubis, 1996. Hukum Perjanjian Dalam Islam. Sinar Grafika, Jakarta.

Perangin, Efendi, 199I. Praktik Penggunaan Tanah Sebagai Jaminan Kredit. Rajawali Press, Jakarta. , 1994. Praktik Jual Beli Tanah. Raja Grhafindo Persada, Jakarta.

Pesoko, Herawati, 2007. Parate Executie Obyek Hak Tanggungan (Inkonsistensi, Konflik Norma dan Kesesatan Penalaran Dalam UUHT). Laksbang Persindo.Yogyakarta.

Prodjodikoro, Wirjono, 1985. Hukum Perdata Tentang Persetujuan Tertentu. Cet.VIII, Sumur, Bandung.

Putra, Ida Bagus Wyase, 2001. Tanggung Jawab Negara Terhadap Dampak Komersialisasi Ruang Angkasa. PT. Refika Adhitama, Bandung.

Mallor, P.,Jane, et.al, 2007.Busines Law; The Ethical, Global, And E-Commerce Environmental. McGraw Hill Companies,Inc., New York.

Raharjo, Sajipto, 2000. Ilmu Hukum. PT. Citra Adhitia Bakti, Bandung.

Richards, Paul, 2004. Law Of Contrakt. Pearlson Education Limited. England.

Ridwan, HR.<2006, Hukum Administrasi Negara, PT. RajaGrhafindo Persada, Jakarta.

Ruhiyat, Eddy, 1983. Pelaksanaan Landreform dan Jual Gadai Tanah, Berdasarkan Undang-Undang No.56 Prp Th 1990. Armico, Bandung.

Salih, Wntjik, 1977. Hak Anda Atas Tanah. Galia Indah, Jakarta.

Salem,HS., H2004, Perkembangan Hukum Jaminan Di Indonesia, PT. Raja Grafindo Persada, Jakarta.

Santosa Az, Lukmann, 2011. Hak dan Kewajiban Hukum Nasabah Bank. Pustaka Yustisia, Yogyakarta.

Santosa, Urip, 2005. Hukum Agraria dan Hak-Hak Atas Tanah. Prenada Media, Jakarta.

Satrio, J., 1998. Hukum Jaminan, Hak Jaminan Kebendaan, Hak Tanggungan Buku II. PT. Citra Adhitia Bakti, Bandung. 
, 2001, Hukum Perikatan, Perikatan Yang Lahir Dari Perjanjian, Citra Aditya Bakti, Bandung

2002, Hukum Jaminan, Hak-Hak Jaminan Kebendaan, Citra Adhitia Bakti, Bandung.

Sautama Hotma Bako, Ronny, 1995.Hubungan Bank dan Nasabah Terhadap Produk Tabungan dan Deposito. Citra Aditya Bakti, Bandung.

Soedewi Masjhoen Sofwan, Sri,Hukum Jaminan di Indonesia Pokok-Pokok Hukum Jaminan dan Jaminan Perorangan, Liberti, Yogyakarta.

Soehino, 1998. Ilmu Negara. Liberty, Jogyakarta.

Soekanto, Soerjono, 1983,Hukum Adat Indonesia. Rajawali, Jakarta , 1983, Penegakan Hukum, Binacipta, Bandung. , 2001. Sosiologi Suatu Pengantar. Raja Grhafindo Persada, Jakarta.

Soemardjono, SW.,Maria, 2009.Tanah dalam pespektif hak ekonomi, sosial dan budaya. Kompass, Jakarta.

Soeroso, R., 2010. Perjanjian Di Bawah Tangan, Pedoman Praktis Pembuatan Dan Aplikasi Hukum. Sinar Grafika. Jakarta.

Soimin, Soedaryo, 2004. Status Hak Dan Pembebasan Tanah. Sinar Grafika, Jakarta.

Subekti, R., 1982. Law In Indonesia, Centre For Strategic And Internasional, And Studies. Third Edition, Jakarta. , 1987, Hukum Perjanjian, Intermasa, Jakarta.

1991, Jaminan-Jaminan Untuk Pemberian Kredit Menurut Hukum Indonesia, PT. Citra Aditya Bakti, Bandung.

Sudarsono, 1999.Kamus Hukum. PT.Rineka Tjipta, Jakarta.

Sutedi, Adrian, 2010. Hukum Hak Tanggungan. Sinar Grafika, Jakarta. , 2010. Peralihan Hak Atas Tanah Dan Pendaftarannya. Sinar Grafika, Jakarta.

Sri Wibawanti, Erna, dan R.Murjiyanto, 2013. Hak Ats Tanah Dan Peralihannya. Liberti Yogyakarta, Yogyakarta. 
Usfunan, Johannes, 2002. Perbuatan Pemerintah yang Dapat Digugat. Djambatan, Jakarta.

Utsman, Rahmadi, 2009. Hukum Jaminan Keperdataan. Sinar Grafika, Jakarta. , 2012. Mediasi Di Pengadilan Dalam Teori Dan Praktik. Sinar Grafika, Jakarta.

Widjaja, Gunawan, dan Kartini Muljadi, 2003. Penanggungan Utang dan Perikatan Tanggung Menanggung. PT. RajaGrafindo Persada, Jakarta.

Witanto, D.Y, 2011, Hukum Acara Mediasi Dalam Perkara Perdata Di Lingkungan Peradilan Umum Dan Peradilan Agama Menurut PERMA Nomor 1 Tahun 2008 Tentang Prosedur Mediasi Di Pengadilan. Alfabeta, Bandung.

\section{PERATURAN PERUNDANG-UNDANGAN :}

Undang-Undang Dasar Negara Republik Indonesia Tahun 1945.

Kitab Undang-Undang Hukum Perdata (BW) Terjemahan R.Subekti dan R. Tjitrosudibio, 2009, Cetakan XXXX, Pradnya Paramita, Jakarta.

Undang-Undang No. V Tahun 196o Tentang Peraturan Dasar Pokok-Pokok Agraria (Lembaran Negara Tahun 1960 Nomor 104, Tambahan Lembaran Negara Republik Indonesia Nomor 2043).

Undang-Undang No. IV Tahun 1996 Tentang Hak Tanggungan Atas Tanah Beserta Benda-Benda Yang Berkaitan Dengan Tanah (Lembaran Negara Republik Indonesia Tahun 1996 Nomor 42, Tambahan Lembaran Negara Republik Indonesia Nomor 3632).

Undang-Undang No. 1o Tahun 1998 Tentang Perbankan (Lembaran Negara Republik Indonesia Tahun 1998 Nomor I82 Tambahan Lembaran Negara Republik Indonesia Nomor 3790). 